\title{
Does the Reduction of the Local Anesthetic Dose Provide Surgical Anesthesia While Avoiding Maternal Hypotension in Obese Pregnant Women for C/S with Single-shot Spinal Anesthesia?
}

\author{
Lokal Anestezik Dozun Azaltılması, Tek Doz Spinal Anestezi ile C/S Uygulamasında Obez \\ Gebelerde Maternal Hipotansiyonu Önlerken Cerrahi Anestezi Sağlar Mı?
}

\author{
(D) Çiğdem Yıldırım Güçlü, (D) Süheyla Karadağ Erkoç, (D) Başak Ceyda Meço, (1) Volkan Baytaş, (D) Ali Abbas Yılmaz, \\ (1) Hanife Asuman Uysalel \\ Ankara University Faculty of Medicine, Department of Anesthesiology and Reanimation, Ankara, Turkey
}

\section{Abstract}

Objectives: Anesthesia for pregnant patients requires attention because it affects two healthy people: the mother and the baby. Both general and regional anesthesia are options, although regional anesthesia is generally favored. Avoiding maternal hypotension is an important issue during regional anesthesia, and lowering the dose of local anesthetic is one method for this complication. This study was designed to assessment whether a low-dose regimen provides surgical anesthesia in obese pregnant patients while avoiding maternal hypotension.

Materials and Methods: After informed consent was received from 130 patients, they were randomized to four groups according to their body mass index and received $10 \mathrm{mg}$ hyperbaric bupivacaine or $7.5 \mathrm{mg}$ hyperbaric bupivacaine $+25 \mathrm{mcg}$ fentanyl for spinal anesthesia. Hypotension after spinal anesthesia, need for additional anesthetic, technical difficulty with regional anesthesia, Bromage scale score, surgery time, and postoperative analgesic requirements were recorded. Complications and Apgar scores were also recorded.

Results: General anesthesia was administered only to two patients in group II because of ineffective spinal anesthesia. The hemodynamic parameters did not differ among the groups. The analysis revealed no difference among groups in recovery from motor block ( $p=0.235)$, but the groups differed in the duration of postoperative analgesia $(p=0.00)$.

Conclusion: Reducing the local anesthetic dose for obese pregnant patients does not lead to significant differences in hypotension compared with spinal anesthesia in non-obese patients. Adding an opioid may also improve postoperative pain control. Even a low dose of local anesthetic with opioid can maintain surgical anesthesia for cesarean section in obese pregnant patients.

Key Words: Local Anesthetic, Low Dose, Spinal Anesthesia, Obese Pregnant

\section{Öz}

Amaç: Gebe hastalarda anestezi, iki sağııkı insanı (anne ve bebek) etkilediği için dikkat gerektirmektedir. Genellikle rejyonel anestezi tercih edilse de, genel ve rejyonel anestezi birer seçenekdir. Maternal hipotansiyonu önlemek anestezi sırasında önemlidir ve bu komplikasyonu önlemede lokal anestezik dozunu azaltmak bir yöntemdir. Bu çalışma, obez gebelerde düşük doz rejimin, maternal hipotansiyonu önlerken cerrahi anestezi sağlayıp sağlamadığını değerlendirmek için planlanmıştır.

Gereç ve Yöntem: Bilgilendirilmiş onam alınan 130 hasta, vücut kitle indekslerine göre dört gruba randomize edildi ve hastalara spinal anestezi için $10 \mathrm{mg}$ hiperbarik bupivakain veya 7,5 mg hiperbarik bupivakain+25 mcg fentanil uygulandı. Spinal anesteziden sonra hipotansiyon, ek anestezik intiyacı, rejyonel anestezideki teknik zorluk, Bromage skala skoru, cerrahi süre ve postoperatif analjezik gereksinimler kaydedildi. Komplikasyonlar ve Apgar skorları da kaydedildi.

Bulgular: Genel anestezi, başarısız spinal anestezi nedeniyle sadece grup II'deki iki hastaya uygulandı. Hemodinamik parametreler gruplar arasında farklılık göstermedi. Motor bloğun düzelmesinde gruplar arasında fark olmadığı $(p=0,235)$, ancak postoperatif analjezi süresinde farklılık olduğu görüldü $(p=0,00)$.

Address for Correspondence/Yazışma Adresi: Öğr. Gör. Süheyla Karadağ Erkoç,

Ankara University Faculty of Medicine, Department of Anesthesiology and Reanimation, Ankara, Turkey

Phone: +90 5063994839 E-mail: suheylakaradag@hotmail.com ORCID ID: orcid.org/0000-0001-5086-5916

Received/Geliş Tarihi: 10.10.2019 Accepted/Kabul Tarihi: 21.10.2019

๑Copyright 2019 Ankara University Faculty of Medicine

Journal of Ankara University Faculty of Medicine is published by Galenos Publishing House.

All content are under CC BY-NC-ND license. 
Sonuç: Obez gebelerde lokal anestezik dozunu azaltmak, obez olmayan hastalarda spinal anestezi ile karşılaştırıldığında hipotansiyonda anlamlı farklılıklara yol açmaz. Bir opioid eklemek, ameliyat sonrası ağrı kontrolünü iyileştirebilir. Düşük dozda lokal anestezik ile birlikte opioid uygulaması obez gebelerde sezaryen için cerrahi anestezi de sağlayabilir.

Anahtar Kelimeler: Lokal Anestezik, Düşük Doz, Spinal Anestezi, Obez Gebe

\section{Introduction}

Anesthesia for cesarean section requires special attention because it can affect both the mother and the baby. Avoiding maternal hypotension related to spinal anesthesia must be the primary objective of anesthetic management in such cases. Many factors influence the effectiveness of sensory nerve block for surgical anesthesia; the local anesthetic dose is the main determinant (1). The use of a lower local anesthetic dose for spinal anesthesia is the most common method for avoiding maternal hypotension during spinal anesthesia (2). Many studies have investigated the use of different dose regimens for cesarean anesthesia.

Another factor that influences the sensory nerve block is the obesity related to pregnancy. Due to the enlargement of the epidural venous plexus during pregnancy, the subarachnoid and epidural space diminishes; hence, the local anesthetic requirement also decreases. Many investigators recommend the use of a lower dose of local anesthetic in obese patients due to their reduced anesthetic requirement (3-5). Although a common approach for the obese patient is to reduce the local anesthetic dose, the literature provides confusing findings $(6,7)$. In a modified up-down method study, the required dose of intrathecal bupivacaine for cesarean was similar for obese and normal-weight women (8).

While reducing the local anesthetic dose, surgical anesthesia becomes another issue. The combination of anesthesia with opioids offers another solution. In addition to maintaining a more intense sensory block, adding opioids, such as fentanyl, to a local anesthetic also decreases maternal hypotension, vasopressor requirements, nausea, and time to discharge from the post-anesthesia care unit (2).

Many studies have examined dosing regimens for cesarean anesthesia, but an ideal dose has not been found. We designed this study to compare the effects of conventional dosing (10 mg bupivacaine) with those of low-dose anesthesia plus fentanyl ( $7.5 \mathrm{mg}$ bupivacaine $+25 \mathrm{mcg}$ fentanyl) in obese and normal-weight pregnant women undergoing cesarean section. Our hypothesis was that the low-dose regimen would provide surgical anesthesia in obese patients while avoiding maternal hypotension.

\section{Materials and Methods}

The Institutional Ethics Committee of the Ankara University Ethic Committee (approval number: 46004091-302.14.16) approved the study, and written informed consent was obtained from all participating patients. A total of 130 patients were recruited, and 128 completed the study; data for two of the patients were missing. Exclusion criteria were spinal anesthesia contraindications, thrombocytopenia, coagulation defects, cardiomyopathy, placenta previa, twin pregnancy, hypersensitivity to amide local anesthetics or fentanyl, infection at the injection site, and/or neurologic disease.

Upon arrival in the operating room, a 20-gauge intravenous cannula was inserted, and $10 \mathrm{~mL} / \mathrm{kg} 0.9 \% \mathrm{NaCl}$ infusion was administered. After routine monitoring, electrocardiogram, non-invasive blood pressure, and peripheral oxygen saturation were monitored, and baseline systolic arterial pressure $(\mathrm{mmHg})$ and heart rate [(HR) (beats. $\left.\left.\mathrm{min}^{-1}\right)\right]$ were calculated as the mean of three successive measurements taken at intervals of $1 \mathrm{~min}$ with a difference of no more than $10 \%$.

Randomization was based on computer-generated codes (SPSS v13, Inc., Chicago, IL, USA) and kept in sequentially numbered opaque envelopes until just before use.

Under aseptic conditions, lumbar puncture was performed using a 25-gauge spinal needle at the level of the L3-4 interspace with the patient in sitting position. After the free flow of cerebrospinal fluid was achieved, the specified drug for each group was injected slowly over $20 \mathrm{~s}$, with the orifice of the spinal needle pointing cephalically. The patients were moved immediately into supine position. An independent investigator blinded to the anesthetic technique evaluated the effects.

\section{The patients were randomized to four groups:}

Group I: pregnant with BMI (body mass index) $<30$ and undergoing spinal anesthesia with $10 \mathrm{mg}$ hyperbaric bupivacaine

Group II: pregnant with $\mathrm{BMI}<30$ and undergoing spinal anesthesia with $7.5 \mathrm{mg}$ hyperbaric bupivacaine $+25 \mathrm{mcg}$ fentanyl

Group III: pregnant with $\mathrm{BMI} \geq 30$ and undergoing spinal anesthesia with $10 \mathrm{mg}$ hyperbaric bupivacaine

Group IV: pregnant with $\mathrm{BMI} \geq 30$ and undergoing spinal anesthesia with $7.5 \mathrm{mg}$ hyperbaric bupivacaine $+25 \mathrm{mcg}$ fentanyl 
Hypotension, defined as a systolic blood pressure (SBP) $<100$ $\mathrm{mmHg}$ or a 30\% decrease from baseline, was treated with $5 \mathrm{mg}$ ephedrine and repeated as required. The number of doses of vasopressors administered and the time from spinal injection to the first appearance of hypotension were documented.

Spinal block was tested using cold water. The time intervals from the completion of the spinal injection to achieving a T6 block (defined as the onset time of anesthesia), duration of surgery, maximal sensory dermatome extension, and end of motor block (Bromage 0) and sensory dermatome extension at the end of surgery were recorded. Lower limb motor blockade was assessed using the modified Bromage scale $(0=$ no impairment; $1=$ unable to raise extended legs but able to move knees and ankles; $2=$ unable to raise extended legs or flex knees, able to move feet; $3=$ unable to flex ankles, knees or hips) immediately before surgical incision and at the end of surgery. Technical difficulty was scored (0: no difficulty, 1: difficulty with palpation, 2: difficulty with puncture, and 3: difficulty with both palpation and puncture), and the values were recorded.

An intraoperative pain assessment was performed using a visual analog scale (VAS) $(0-10 \mathrm{~cm}$, where $0=$ no pain and $10=$ worst pain ever felt). The duration of effective analgesia was measured from the time of intrathecal injection to a VAS score $\geq 4$, including the post-surgery period. Side effects such as nausea, vomiting, and pruritus were noted. Apgar scores were measured at 1 and 5 min post-delivery.

When VAS $>4$, a sedative agent (20 mg propofol) was administered; if the patient still experienced pain then general anesthesia was performed.

\section{Statistical Analysis}

The data analysis was performed using statistical software (SPSS for Windows, version 15, SPSS, Inc., Chicago, IL, USA). Descriptive statistics with normal distribution are expressed as the mean \pm standard deviation, abnormally distributed descriptive statistics are expressed as median (min-max), and nominal variables are expressed percentages. ANOVA (analysis of variance) was used to evaluate the differences in mean values between groups, and the Kruskal-Wallis test was used for median values. Nominal variables were evaluated using the Pearson $\chi^{2}$ test (chi-square test) or Fisher's exact test.

The change between before and after the treatment periods was evaluated using the paired t-test if the disturbance was normal and Wilcoxon's test if the disturbance was not normal. Repeated values according to time were assessed using ANOVA if the disturbance was normal and Friedman's test if the disturbance was not normal. The relationship between continuous variables was examined using Spearman or Pearson correlation tests according to disturbance. Statistical significance was defined as $p \leq 0.05$.

The total sample of 128 subjects was adequate to achieve $78 \%$ power to detect differences among the means versus the alternative of equal means according to an $\mathrm{F}$ test with a 0.05 significance level for SBP.

\section{Results}

The age and gestational age of the pregnant women were similar among the groups (Table 1). The time required to reach T6 sensory nerve block was also similar ( $p=0.079$; Table 1$)$. The Bromage scores at the beginning of surgery were as follows: 2 (1-3), 3 (1-3), 3 (1-3), and 3 (2-3) for Groups I, II, III and IV, respectively, $p=0.014$. The differences in scores were significant due to the difference between group I and IV, which had a $\mathrm{p}$ value of 0.009 (Table 1).

Regarding technical difficulties, most of the patients in Groups I and II were scored as 1, most patients in Group III were scored as 2, and most of the patients in Group IV were scored as 1 (Table 2).

No statistically significant difference emerged among the groups in the means of vasopressor requirements or in the vasopressor requirements and the time to the beginning of the surgery $(p=0.079,0.004,0.031$, and 0.014 , respectively; according to the Bonferroni correction, $\mathrm{p}$ should be smaller than 0.0125 to be meaningful). Additionally, no relationship was detected between vasopressor administration time and the beginning of surgery in any of the groups.

\begin{tabular}{|c|c|c|c|c|c|}
\hline & $\begin{array}{l}\text { Group I } \\
(n=32)\end{array}$ & $\begin{array}{l}\text { Group II } \\
(n=32)\end{array}$ & $\begin{array}{l}\text { Group III } \\
(n=30)\end{array}$ & $\begin{array}{l}\text { Group IV } \\
(\mathrm{n}=33)\end{array}$ & $\mathbf{p}$ \\
\hline Age (years) (mean \pm SD) & $27.8 \pm 5.13$ & $27.6 \pm 4.4$ & $29.2 \pm 6.2$ & $29.3 \pm 4.8$ & 0.0408 \\
\hline Gestational age (weeks) (mean \pm SD) & $37.7 \pm 1.54$ & $38.2 \pm 1.96$ & $38.4 \pm 1.24$ & $38.3 \pm 1.81$ & 0.202 \\
\hline Time required to achieve T6 block (min) (median, min-max) & $4(2-8)$ & $5(3-8)$ & $4(2.3-7)$ & $5(3-8)$ & 0.079 \\
\hline Bromage scale at the beginning of surgery (median, min-max) & $2(1-3)$ & $3(1-3)$ & $3(1-3)$ & $3(2-3)$ & $0.014^{*}$ \\
\hline $\begin{array}{l}\text { Time between spinal anesthesia and the beginning of surgery } \\
\text { (min) (median, } \min -\max )\end{array}$ & $3(2-10)$ & $5(2-10)$ & $3(2-7)$ & $4(2-10)$ & $0.000^{*}$ \\
\hline Surgery time (min) (median, min-max) & $23.5(14-46)$ & $27.5(17-55)$ & $30(16-76)$ & 25 (14-76) & $0.02^{*}$ \\
\hline
\end{tabular}


The sensory nerve block levels at the end of the surgery were similar for all the groups. The medians of each group were T6 (T3-T10), T7 (T3-T10), T6 (T3-T10), and T6 (T3-T10), respectively $(p=0.049)$. The analysis revealed no difference among the groups in the recovery of motor block ( $p=0.235$ ), but the groups differed in the duration of postoperative analgesia $(p=0.00$; Table 3). The need for pain relief was observed at $124.5 \mathrm{~min}$ (55-338), $175 \mathrm{~min}$ (63-365), $135 \mathrm{~min}$ (53-344), and $205 \mathrm{~min}$ (93-468) after the surgery, respectively, for Groups I through IV

\begin{tabular}{|c|c|c|c|c|}
\hline Technical difficulty & $\begin{array}{l}\text { Group I } \\
(n=32)\end{array}$ & $\begin{array}{l}\text { Group II } \\
(n=32)\end{array}$ & $\begin{array}{l}\text { Group III } \\
(n=30)\end{array}$ & $\begin{array}{l}\text { Group IV } \\
(n=33)\end{array}$ \\
\hline 0 & $\begin{array}{l}0 \\
0.0 \%\end{array}$ & $\begin{array}{l}0 \\
0.0 \%\end{array}$ & $\begin{array}{l}4 \\
13.3 \%\end{array}$ & $\begin{array}{l}0 \\
0.0 \%\end{array}$ \\
\hline 1 & $\begin{array}{l}26 \\
81.2 \%\end{array}$ & $\begin{array}{l}31 \\
96.6 \%\end{array}$ & $\begin{array}{l}9 \\
30 \%\end{array}$ & $\begin{array}{l}23 \\
69.7 \%\end{array}$ \\
\hline 2 & $\begin{array}{l}3 \\
9.4 \%\end{array}$ & $\begin{array}{l}1 \\
3.1 \%\end{array}$ & $\begin{array}{l}12 \\
40 \%\end{array}$ & $\begin{array}{l}10 \\
30.3 \%\end{array}$ \\
\hline 3 & $\begin{array}{l}3 \\
9.4 \%\end{array}$ & $\begin{array}{l}0 \\
0.0 \%\end{array}$ & $\begin{array}{l}5 \\
16.7 \%\end{array}$ & $\begin{array}{l}0 \\
0.0 \%\end{array}$ \\
\hline
\end{tabular}

Table 3: Motor recovery time (Bromage 0 ) and duration of postoperative analgesia

\begin{tabular}{|c|c|c|c|c|c|}
\hline & $\begin{array}{l}\text { Group I } \\
(n=32)\end{array}$ & $\begin{array}{l}\text { Group II } \\
(n=32)\end{array}$ & $\begin{array}{l}\text { Group III } \\
(n=30)\end{array}$ & $\begin{array}{l}\text { Group } \\
\text { IV } \\
(n=33)\end{array}$ & p \\
\hline $\begin{array}{l}\text { Motor } \\
\text { recovery time } \\
\text { (min) } \\
\text { (median, } \\
\text { min-max) }\end{array}$ & $\begin{array}{l}172.5 \\
(89-293)\end{array}$ & $\begin{array}{l}148 \\
(32-338)\end{array}$ & $\begin{array}{l}146.5 \\
(65-284)\end{array}$ & $\begin{array}{l}121 \\
(50-333)\end{array}$ & 0.235 \\
\hline $\begin{array}{l}\text { Duration of } \\
\text { postoperative } \\
\text { analgesia } \\
\text { (min) } \\
\text { (median, } \\
\text { min-max) }\end{array}$ & $\begin{array}{l}124.5 \\
(55-338)\end{array}$ & $\begin{array}{l}175 \\
(63-365)\end{array}$ & $\begin{array}{l}135 \\
(53-344)\end{array}$ & $\begin{array}{l}205 \\
(93-468)\end{array}$ & 0.000 \\
\hline min: Minimum, ma & k: Maximum & & & & \\
\hline
\end{tabular}

$(p=0.00)$. Statistically significant differences emerged between Groups I and II ( $p=0.048)$, Groups I and IV ( $p=0.001)$, and Groups III and IV ( $p=0.004)$.

The hemodynamic parameters also did not differ among the groups. At all follow up periods, the HR's and mean systolic pressure were similar for all the groups (Table 4).

General anesthesia was administered only to two patients in Group II because of failed spinal anesthesia. Three patients in Group I and two patients in Group III required sedation or supplemental analgesia. None of the patients in Group IV needed any other medication for anxiety or pain.

Complications, such as nausea, vomiting, bradycardia, and itching, were followed up. Nausea was the most common complication in all the groups and was reported by $67.4 \%$ of the patients. No statistically significant difference was found in the means of complications across groups ( $p=0.072)$.

The analysis revealed no significant difference among the groups in Apgar scores at 1 and 5 mins after birth.

\section{Discussion}

This study compared the effects of a lower dose of bupivacaine plus fentanyl with those of the conventional dose of bupivacaine in obese and non-obese pregnant patients using surgical anesthesia for cesarean section. The conventional dose is the one we use in our clinical practice during cesarean operations. The aim of using the lower dose was to prevent hypotension related to spinal anesthesia. The rate of maternal hypotension did not differ between the obese and non-obese patients, but the lower dose was able to maintain surgical anesthesia in obese pregnant patients during cesarean section.

Pregnant patients are of special concern because any complication will affect both the mother and the baby. Spinal anesthesia is the preferred method for cesarean section, and hyperbaric bupivacaine being used in many countries

Table 4: Systolic blood pressure values during surgery

\begin{tabular}{|c|c|c|c|c|c|}
\hline & Group I & Group II & Group III & Group IV & p \\
\hline SBPB & $125.9 \pm 13.8$ & $127.6 \pm 12.4$ & $135.8 \pm 14$ & $133.8 \pm 13.1$ & 0.009 \\
\hline SBPS & $121.7 \pm 15$ & $120.5 \pm 15.6$ & $130.4 \pm 15.8$ & $123.4 \pm 15.3$ & 0.056 \\
\hline SBP4 & $136.7 \pm 16.4$ & $106 \pm 22.2$ & $108.4 \pm 21.8$ & $110.7 \pm 20.7$ & 0.433 \\
\hline SBP6 & $107 \pm 17$ & $111.9 \pm 19$ & $105.7 \pm 14.2$ & $111.2 \pm 14.2$ & 0.421 \\
\hline SBP10 & $116.1 \pm 14.4$ & $116.4 \pm 14.5$ & $120.7 \pm 10.9$ & $120.3 \pm 20.3$ & 0.499 \\
\hline SBP15 & $112.8 \pm 12.6$ & $120.1 \pm 11.5$ & $118.7 \pm 15.2$ & $121.4 \pm 14$ & 0.057 \\
\hline SBP20 & $114.5 \pm 13.2$ & $117.1 \pm 14.7$ & $117.5 \pm 14.2$ & $113.3 \pm 23.2$ & 0.718 \\
\hline SBPS & $111.7 \pm 29.5$ & $117.2 \pm 10$ & $125.5 \pm 11.9$ & $118.8 \pm 11.7$ & 0.112 \\
\hline
\end{tabular}


(9). Many dose regimens have been applied with the aim of avoiding maternal hypotension, and while low-dose anesthesia is generally preferred, it may not be suitable for all patients or may be inadequate (10). When minimizing maternal and neonatal side effects by lowering the spinal anesthesia dose, it is important to maintain surgical anesthesia during cesarean section.

In obese patients, spinal anesthesia is suggested to be administered at lower doses for such reasons as increased abdominal pressure from abdominal fat, epidural venous plexus engorgement secondary to compression of the inferior vena cava, and diversion of venous return (11). Studies of obese pregnant patients have provided conflicting results $(6,12)$. The results of this study confirmed that the spinal anesthesia doses for obese and non-obese pregnant women did not differ. Consistent with the finding by Aiono-Le Tagaloa et al. (9), we did not find a significant difference in the mean time to reach the T6 sensory level (13).

In the study by Venkata et al. (14), hyperbaric bupivacaine together with fentanyl reached the T6 sensory level faster compared than other regimens, but the groups in that study were not classified as obese and non-obese as in our study.

The hemodynamics were similar among the groups. Systolic and diastolic blood pressure and HR did not differ significantly. The need for vasopressors, which indicates hypotension after spinal anesthesia, was similar across groups regardless of the anesthesia dose. This issue is still unclear due to different findings. Our study is not the first to show no difference in dosage between obese and non-obese patients. Norris (6) and Hartwell et al. (15) also found that BMI had no effect on spinal anesthesia in women undergoing cesarean section (14). Moreover, in the study by Lee et al. (8), a similar dose requirement was found for obese and non-obese patients undergoing cesarean section.

Technical difficulty is a problem that we can address during anesthesia management for obese patients. Our study showed that a BMI $\geq 30$ could affect the performance of spinal anesthesia. We found that having obese patients adopt a sitting position during spinal anesthesia may ease the procedure.

Adding opioids to the local anesthetic could achieve faster recovery from the motor block after spinal anesthesia. In this study, no significant difference was detected between the groups that received added opioid and the local anestheticonly groups. This result may be related to the low dose of local anesthetic. In fact, Turhanoglu et al. (16) reported results similar to ours with $4 \mathrm{mg}$ bupivacaine. However, adding the opioid affected postoperative pain after the surgery, meaning that the fentanyl groups required analgesia later than the other groups.

Reducing the dose of intrathecal bupivacaine may help to reduce maternal hypotension, decrease vasopressor requirements, and improve maternal satisfaction, although care must be taken to ensure that anesthesia is maintained during surgery (2). In this study, the spinal anesthesia failed in two patients in Group II, which does not support any of our hypotheses. In these cases, the low anesthesia dose could have been the factor. In Groups III and I, only one patient required additional analgesia. In Group IV, none of the patients required supplemental medication. This result confirmed that low-dose local anesthesia with opioid in obese patients maintains surgical anesthesia for cesarean section. Low doses of $5 \mathrm{mg}$ and $8 \mathrm{mg}$ of intrathecal bupivacaine alone have been associated with visceral pain and discomfort $(2,17)$.

On the other hand, Turhanoglu et al. (16) achieved surgical anesthesia for cesarean section with intrathecal $4 \mathrm{mg}$ bupivacaine and $25 \mathrm{mcg}$ fentanyl.

In the current study, all the groups were similar in terms of patient satisfaction, which is an important issue for the outcome of the study.

\section{Study Limitations}

As a limitation of this study, epidural catheter may be used as a rescue technique when spinal anesthesia failed.

Pregnant women who are obese also may have a difficult airway. In addition to the difficulty associated with regional techniques, general anesthesia and airway management may be problematic in these patients. All difficult airway preparations must be ready in case airway management is required.

\section{Conclusion}

To conclude, lowering the local anesthetic dose for obese pregnant patients does not lead to significant differences in hypotension related to spinal anesthesia in non-obese patients. Adding opioid medication may also help control postoperative pain. This study highlights that a single shot of spinal anesthesia may offer adequate surgical anesthesia for obese patients undergoing cesarean section. Even a low dose of local anesthetic with opioid can maintain surgical anesthesia for cesarean section in obese pregnant women. However, these results still cannot determine the ideal anesthetic dose for pregnant patients. Future studies are needed to find the best dose regimen for spinal anesthesia for cesarean section, although there may not be a single best regimen for this group of patients, and anesthesia may need to be individualized.

\section{Ethics}

Ethics Committee Approval: The Institutional Ethics Committee of the Ankara University Ethic Committee (approval number: 46004091-302.14.16) approved the study. 
Informed Consent: Written informed consent was obtained from all participating patients.

Peer-review: Externally peer-review.

\section{Authorship Contributions}

Surgical and Medical Practices: Ç.Y.G., S.K.E., H.A.U., Concept: Ç.Y.G., S.K.E., Design: A.A.Y., Data Collection or Processing: Ç.Y.G., S.K.E., Analysis or Ç.Y.G., B.C.M., Writing: Ç.Y.G., B.C.M., A.A.Y., V.B.

Conflict of Interest: No conflict of interest was declared by the authors.

Financial Disclosure: The authors declared that this study received no financial support.

\section{References}

1. Hocking $\mathrm{G}$, Wildsmith JA. Intrathecal drug spread. $\mathrm{Br} J$ Anaesth. 2004;93:568-578.

2. Ben-David B, Miller G, Gavriel R, et al. Low-dose bupivacaine-fentanyl spinal anesthesia for cesarean delivery. Anesth Pain Med. 2000;25:235-239.

3. Roofthooft E. Anesthesia for the morbidly obese parturient. Curr Opin Anaesthesiol. 2009;22:341-346.

4. Soens MA, Birnbach DJ, Ranasinghe JS, et al. Obstetric anesthesia for the obese and morbidly obese patient: an ounce of prevention is worth more than a pound of treatment. Acta Anaesthesiol Scand. 2008;52:6-19.

5. Brodsky JB, Lemmens HJ. Regional anesthesia and obesity. Obes Surg. 2007;17:1146-1149.

6. Norris MC. Height, weight, and the spread of subarachnoid hyperbaric bupivacaine in the term parturient. Anesth Analg. 1988;67:555-558.
7. Norris MC. Patient variables and the subarachnoid spread of hyperbaric bupivacaine in the term parturient. Anesthesiology. 1990;72:478-482.

8. Lee $Y$, Balki M, Parkes $R$, et al. Dose requirement of intrathecal bupivacaine for cesarean delivery is similar in obese and normal weight women. Rev Bras Anestesiol. 2009;59:674-683.

9. Aiono-Le Tagaloa L, Butwick AJ, Carvalho B. A survey of perioperative and postoperative anesthetic practices for cesarean delivery. Anesthesiol Res Pract. 2009;2009:510642.

10. Arzola C, Wieczorek PM. Efficacy of low-dose bupivacaine in spinal anaesthesia for Caesarean delivery: systematic review and meta-analysis. $\mathrm{Br}$ J Anaesth. 2011;107:308-318.

11. Hogan $\mathrm{QH}$, Prost $\mathrm{R}$, Kulier $\mathrm{A}$, et al. Magnetic resonance imaging of cerebrospinal fluid volume and the influence of body habitus and abdominal pressure. Anesthesiology. 1996;84:1341-1349.

12. Taivainen $T$, Tuominen M, Rosenberg PH. Influence of obesity on the spread of spinal analgesia after injection of plain $0.5 \%$ bupivacaine at the L3-4 or L4-5 interspace. Br J Anaesth. 1990;64:542-546.

13. Carvalho B, Durbin M, Drover DR, et al. The ED50 and ED95 of intrathecal isobaric bupivacaine with opioids for cesarean delivery. Anesthesiology. 2005;103:606-612.

14. Venkata $H G$, Pasupuleti $S$, Pabba UG, et al. A randomized controlled prospective study comparing a low dose bupivacaine and fentanyl mixture to a conventional dose of hyperbaric bupivacaine for cesarean section. Saudi J Anaesth. 2015;9:122-127.

15. Hartwell BL, Aglio LS, Hauch MA, et al. Vertebral column length and spread of hyperbaric subarachnoid bupivacaine in the term parturient. Reg Anesth. 1991;16:17-19.

16. Turhanoglu $\mathrm{S}$, Kaya $\mathrm{S}$, Erdogan $\mathrm{H}$. Is there an advantage in using low-dose intrathecal bupivacaine for cesarean section? J Anesth. 2009;23:353-357.

17. Choi DH, Ahn HJ, Kim MH. Bupivacaine-sparing effect of fentanyl in spinal anesthesia for cesarean delivery. Anesth Pain Med. 2000;25:240-245. 